\title{
Depression and Cognitive Decline: Factors Related to Demographics and Psycho Pharmacotherapy on Elderly in Nursing Homes
}

Edvaldo Soares ${ }^{1^{*}}$ and Patrícia de Souza Rossignoli ${ }^{2}$

${ }^{1,2}$ Sao Paulo State University, Laboratory of Cognitive Neuroscience-LaNeC

*Corresponding author: Edvaldo Soares, Sao Paulo State University, Av. Hygino Muzzi Filho, 737,Marilia, São Paulo, Brazil. CEP: 17500-090; Tel: 551434021371; E-mail: edsoares@marilia.unesp.br

Received Date: May 5, 2014, Accepted Date: September 23, 2014, Published Date: September 30, 2014

Copyright: (c) 2014, Edvaldo Soares et al., This is an open-access article distributed under the terms of the Creative Commons Attribution License, which permits unrestricted use, distribution, and reproduction in any medium, provided the original author and source are credited.

\begin{abstract}
Objectives: To identify the prevalence of neuropsychiatric disorders, especially DP and CD, on a sample of nursing home residents, relating this prevalence with some aspects of the demographics and psycho pharmacotherapy.

Methods: 48 elders from two different nursing homes were selected. The collection of demographic and pharmacological data was made utilizing medical records. The medication was classified according to the Anatomical Therapeutic Chemical Code (ATC) criteria. The Geriatric Depression Scale (GDS 30) and the Mini Mental State Examination (MMSE) tests were utilized to determine the prevalence of DP and CD.

Results: It was observed in the sample a high incidence of DP and CD among the researched elders. More schooling individuals tend to present less CD. Individuals with less CD indicatives present less symptomatology for DP. Of all the researched elders, $54,2 \%$ are submitted to psycho pharmacotherapy. Of all the consumed medicine, $16,5 \%$ belonged to the class of neuropsychiatric medicine. The medicated elders present, in average, a larger symptomatology for DP (12 points/average/GDS) than the non-medicated elders (9,9 points/average/GDS). The inverse occurs in relation to the $C D$ indicatives. The use of psychotropics, especially in association, can have negative effects related to depression and cognition.
\end{abstract}

Discussion: The pharmacotherapy, characterized for the polymedication and chronicity, especially of neuropsychiatric medicines, deserves special attention among elders, because the data suggest a significant relation between the utilization of medicines, singly or in association, and the increase of CD and DP. In addition, the data suggest that DP is a risk factor for CD and DM.

Keywords: Cognitive decline; Depression; Elderly; Nursing home; Psycho pharmacotherapy

\section{Introduction}

The aging of the population is a global phenomenon and has worried professionals of several knowledge areas and public managers. In the developed countries, the growth of the elderly population has been studied for several years. In the emergent and/or development countries, just recently this theme has aroused a larger interest. In Brazil, the elders represented just $3,2 \%$ of the general population in the 1900 and this number increased to $4,7 \%$ in 1960 , may reach $13,8 \%$ in the year of 2025. Today, we have approximately 11 million people over the age of 60 and projections indicate that we will be the 6th country in the world in number of elders in the year of 2020, with approximately 32 million [1]. According to projections of the Brazilian Institute of Geography and Statistics (IBGE), the life expectancy of the Brazilian population for the years 2013 and 2014 was respectively 74,8 and 75,1 years. However, Brazil will continue to grow in terms of average life expectancy of the population, being able to reach in 2020 a life expectancy of 76,7 years and, in 2060, 81,2 years [1].

Has called attention the increasing incidence of neuropsychiatric disorders in the elderly population, including the cognitive decline (CD), dementia (DM) and depression (DP) as the most common pathologies [2]. Changes experienced by the old age, such as the lost of a spouse, the decline of physical and cognitive capacity and the admission to nursing homes can be the breaking point for the emergence of neuropsychiatric disorders [3].

In Brazil, the incidence of DM on elders resident on the community reaches the rate of 13,8 per 1000 habitants/year, and for Alzheimer Disease $(\mathrm{AD})$ the rate is 7,79 . DP has prevalence rates between $5 \%$ and $35 \%$, ranging according to severity level. The prevalence of DP in the population over 65 years of age in Brazil reaches up to $14,3 \%[4,5]$. At average, the prevalence of geriatric DP on elderly in nursing homes is $60 \%$ and on elders that live in the community is $10 \%$ [6], which according to Lebowitz and collaborators generates great impact on the health services [7]. It is noteworthy that the majority of the cases manifest more somatic and cognitive symptoms than mood alterations [8-10], and there are indicatives that DP is an important risk factor for $\mathrm{CD}$ and DM [11-13].

DSM-IVTR (Diagnostic and Statistical Manual of Mental Disorders) defines DM as a syndrome characterized by the memory decline associated to the impairment of at least one other cognitive function (language, gnosias, praxis or executive functions) with enough intensity to interfere on the social or professional performance of the individual [14]. 
In turn, $\mathrm{CD}$ can be a consequence to a mood disorder, use of certain medicines, traumas, etc, and/or be a result of physiological processes related to normal aging or even from a stage of transition to DM. CD, which can vary from light to severe, is considered a heterogeneous entity in its characteristics and clinical trajectory. Therefore, individuals with light CD may evolve to DM or remain stable. Studies show that elders with CD (particularly those with episodic memory deficit) present a larger risk of developing AD. However, on elderly populations it is more common the development of a light CD [15]. It is important to point out that researches indicate the schooling as a protection factor to CD and DM [16,17]. The growing condition of neuropsychiatric disorders among the elderly, along with the occurrence of other chronic diseases, has been responsible for increasing the use of medicines in this age group, which represents $50 \%$ of the medicine consumers $[18,19]$ and the population with a higher index of polymedication [20]. The majority of the elders utilize in a continuous manner at least one medicine, and that the average of the medicine utilized by these individuals is between two and five medicines $[21,22]$. The literature has pointed out that the higher the quantity of medicine consumed, the higher is the risk of problems related to medicine (PRMs) emerge [23]. In this sense, the low number of medicine used, the absence of medicine contraindicated to the age group and the absence of associations that may provoke potentially dangerous medicine interactions are indicatives of an adequate pharmacotherapy for the elders [24-26].

Furthermore, the neuropsychiatric status of the elderly, along with other factors such as social exclusion, prevalence of chronic diseases, absence of familiar environment/structure to supplement the elders' necessities [27], has been considered as a determinant of Elders' admission in Elders Long Permanence Institutions (ELPIs), also known in Brazil as "nursing homes". With the process of admission in nursing homes, elders start to live in a poor environment in terms of physical, cognitive and social stimulation and start to fit themselves in a category of people deprived of projects, family and friends interactions, estranged from their own household, out of the context in which their life's history was built [28]. This way, the context that evolves the admission in nursing homes process sensitively collaborates for the installation or aggravation of neuropsychiatric disorders on elderly. Thus, the aim of the present study was to identify the prevalence of neuropsychiatric disorders, especially DP and CD, on a sample of nursing home residents, relating this prevalence with some aspects of the demographics and psycho pharmacotherapy.

\section{Methods}

The research was performed in two nursing homes located in the city of Marilia-São Paulo, Brazil. The elders were selected after the initial interview, according to the eligibility criteria established, which considered only the elders that presented hearing, linguistic and cognitive capacities sufficient to comprehend and answer the questions and tests fixed for the research. For this study, a sample of 48 elders was selected. Demographic and general health data were collected from the medical records of the selected elders. For the gathering of data related to the incidence of DP, the Geriatric Depression Scale (GDS-30) was applied [29] and, for the incidence of CD, the Mini Mental (MMSE) [30] was applied. For the GDS-30, the following cut-off points were considered: $0-10$ points (normal) and 11 or more (probable DP). From this cut-off point, the following classification was defined, as indicated in other studies: without DP (up to 10 points); light DP (11 to 20 points); moderate to severe DP
(21 to 30 points). It is important to point out that, for the diagnosis of DP, considering the criteria of CID-10, the 10 cut-off point presents sensibility of $100 \%$ and specificity of $88 \%$ [31]. For the Mini Mental State Examination (MMSE) the following cut-off points were adopted: among the elderly with some schooling it was utilized the cut-off of 24 $(0-24=$ cognitive decline indicative; 25 or more=normal) and for the elderly with no schooling, the cut-off point of $19(0-19=$ cognitive decline indicative; 20 or more $=$ normal) $[32,33]$.

The gathering of the psycho pharmacotherapy administrated to the elders was performed in the nursing home's infirmaries. The classification of the neuropsychiatric medicine administrated was defined from the classification criteria of the Anatomical Therapeutic Chemical Code (ATC) [34]. The four levels defined on ATC were taken under consideration: anatomical groups (1st level); main therapeutic groups (2nd level); therapeutic-pharmacological subgroup (3rd level) and therapeutic/pharmacological/chemical subgroup (4th level). The data were tabulated and descriptively analyzed. For the statistical analysis was used the SPSS software for Windows, version 20.0. Differences among the groups were analyzed with the Student $t$ test; to verify the association between gender, schooling, DP and CD indicatives the Pearson $\mathrm{x}^{2}$ test was utilized and, due to a theoretical restriction, the Fisher Exact Text (FET). It was adopted a 5\% probability level for the rejection of the nullity hypothesis on all the tests.

This study was in conformity with the ethical principles indicated in the 196/96 resolution of the National Health Consul - Brazil's Ministry of Health. The execution of the research was approved by the Research's Ethical Committee of the Faculdade de Filosofia e CiênciasFFC of the Universidade Estadual Paulista - UNESP, Marília, São Paulo, Brazil (n. 1198/2010).

\section{Results}

\section{Subjects}

Among the 48 elders of this study, the most part of them were between 77-82 years old (Table 1). The general average, in terms of age, was 74,5 years old $[\mathrm{dp}=8,5]$. Related to gender, 24 [50\%] were male and 24 [50\%] were female, and the average age was 74,4 years old to female and 74,5 to male. Considering the schooling, the most part of elders is literate, and among the male elders the literate rate is bigger than female (Table 2).

\begin{tabular}{|l|l|l|}
\hline Age & \% & $\mathbf{n}$ \\
\hline $59-64$ & 16,7 & 8 \\
\hline $65-70$ & 16,7 & 8 \\
\hline $71-76$ & 25 & 12 \\
\hline $77-82$ & 29,2 & 14 \\
\hline $83-89$ & 12,5 & 6 \\
\hline Total & 100 & 48 \\
\hline
\end{tabular}

Table 1: Distribution of 48 elders admitted in nursing homes according to age in the city of Marília, São Paulo, Brazil, in the year of 2013. 
Page 3 of 9

\section{Neuropsychiatric Disorders}

In relation to the prevalence of DP, 24 [50\%] presented light DP. The others 24 [50\%] did not present any level of DP. There is a greater prevalence of DP among the male elders. However, no difference was observed between the genders in the average score obtained on GDS ( $p>0,05$; Table 3). Related to the age, data indicate a larger prevalence of DP on elders over 70 years old, revealing a positive regular correlation between age and DP ( $r$ Pearson=0,557; $\mathrm{p}=0,005)$ for this sample (Table 4).

\begin{tabular}{|l|l|l|l|l|}
\hline Gender & \multicolumn{2}{l|}{ Literate } & \multicolumn{2}{l|}{ Non-literate } \\
\hline & $\%$ & $\mathrm{n}$ & $\%$ & $\mathrm{n}$ \\
\hline Male & 33,3 & 16 & 16,7 & 8 \\
\hline Female & 25 & 12 & 25 & 12 \\
\hline Total & 58,3 & 28 & 41,7 & 20 \\
\hline
\end{tabular}

Table 2: Distribution of 48 elders admitted in nursing homes according to schooling in the city of Marília, São Paulo, Brazil, in the year of 2013 .

\begin{tabular}{|l|l|l|l|l|}
\hline Gender & \multicolumn{2}{|l|}{ With DP } & \multicolumn{2}{l|}{ GDS } \\
\hline & $\%$ & $\mathrm{n}$ & \multicolumn{2}{|l|}{} \\
\hline Male & 58,3 & 14 & $\begin{array}{r}10,1[\mathrm{dp}=5,3] \\
10,3[\mathrm{dp}=6,9]\end{array}$ \\
\hline Female & 41,7 & 10 & \multicolumn{2}{|}{} \\
\hline Total & 100 & 24 & & \\
\hline
\end{tabular}

Table 3: Distribution of 24 elders admitted in nursing homes with DP indicative according to gender in the city of Marília, São Paulo, Brazil, in the year of 2013 .

\begin{tabular}{|l|l|l|}
\hline Age & \multicolumn{2}{|l|}{ With DP } \\
\hline & $\%$ & $\mathrm{n}$ \\
\hline $59-64$ & 12,5 & 3 \\
\hline $65-70$ & 0 & 0 \\
\hline $71-76$ & 50 & 12 \\
\hline $77-82$ & 37,5 & 9 \\
\hline Total & 100 & 24 \\
\hline F.E.T.: $\mathrm{p}=0,005$ & & \\
\hline
\end{tabular}

Table 4: Distribution of 24 elders admitted in nursing homes with DP indicative according to age in the city of Marília, São Paulo, Brazil, in the year of 2013 .

It was identified on the analyzed sample that $26(54,2 \%)$ subjects presented $\mathrm{CD}$. Of this total, 16 [61,6\%] were female and $10[38,4 \%]$ were male. It was not identified a relation between gender and $C D$ $(\mathrm{p}=0,565)$ or schooling and $\mathrm{CD}(\mathrm{p}=0,527)$. However, the absolute numbers indicate a higher prevalence of elders with $\mathrm{CD}$ indicative among the non-literate in comparison to the literate (Table 5). In addition, considering the age, it was identified that, of the elders who presented CD indicative, $50 \%$ of them was between 71 and 89 years old. The results pointed, on this sample, to a negative correlation, although non-significant, between $\mathrm{CD}$ and age.

\begin{tabular}{|l|l|l|l|l|}
\hline \multicolumn{2}{|l|}{ Schooling } & \multicolumn{2}{l|}{ With CD } & \multicolumn{2}{l|}{ Without CD } \\
\hline & $\%$ & $\mathrm{n}$ & $\%$ & $\mathrm{n}$ \\
\hline Literate & 38,5 & 10 & 45,5 & 10 \\
\hline Non-literate & 61,5 & 16 & 54,5 & 12 \\
\hline Total & 100 & 26 & 100 & 22 \\
\hline F.E.T: $\mathrm{p}=0,527$ & & \multicolumn{4}{l}{} \\
\hline
\end{tabular}

Table 5: Distribution of 48 elders admitted in nursing homes with or without $\mathrm{CD}$ indicative according to schooling in the city of Marília, São Paulo, Brazil, in the year of 2013.

Among the 48 studied elders, 16 [33,3\%], in which 10 [20,8\%] were female and $6[12,5 \%]$ were male, presented at the same time DP and $\mathrm{CD}[(+) \mathrm{DP}(+) \mathrm{CD}]$. From the results relative to the presence of DP and/or CD, the elderly were classified into four groups (Table 6). The result of the $\mathrm{X} 2$ Test for the proportions of individuals in the groups was non-significant (pMonte $\operatorname{Carlo}=0,053$ ), indicating that these proportions, related to the presence of $\mathrm{DP}$ and/or $\mathrm{CD}$, were similar on the sample. The results of this study point also to the occurrence of a regular negative correlation between the results of GDS and MMSE $(r=-0,406 ; p=0,049)$, which indicates that the GDS scores decrease when there is an increase on MMSE scores.

\begin{tabular}{|l|l|l|l|l|l|l|l|}
\hline \multicolumn{2}{|l|}{$(+)$ DP (+) CD } & \multicolumn{2}{l|}{$($ (-) DP (+) CD } & \multicolumn{2}{l|}{$(+)$ DP (-) CD } & \multicolumn{2}{l|}{$(-)$ DP (-) CD } \\
\hline$\%$ & $n$ & $\%$ & $n$ & $\%$ & $n$ & $\%$ & $n$ \\
\hline 33,3 & 16 & 21,0 & 10 & 4,2 & 2 & 41,6 & 20 \\
\hline
\end{tabular}

Table 6: Incidence of DP and/or CD on 48 elders admitted in nursing homes in the city of Marília, São Paulo, Brazil, in the year of 2013. Teste: $\chi^{2}=7,667$; gl $=3$; pMonte Carlo $=0,053$

\section{Psychopharmacotherapy}

In relation to the pharmacotherapy of elders, $6[12,5 \%]$ do not consume any type of medicine. Due to the incidence of chronic diseases, 42 elders [87,5\%] consume, without considering the defined daily dosages (DDD), 364 medicines of continuous use per day, which can be translated into an general average of 8,6 medicine/elder/day to the group of medicated elders, with an average of 8,4 medicine/day to male and 9,7 medicine/day to female.

Considering the Anatomical Therapeutic Chemical Code (ATC) criteria, of all the medicine consumed, $62[17,0 \%]$ belonged to the anatomical group of nervous system $(\mathrm{N})$, distributed according to the subgroups presented in Table 7. It was observed that female elders are more medicated than male, consuming an average of 1,8 neuropsychiatric medicine/day against 1 neuropsychiatric medicine/day to male. It was also possible to observe that there is a higher consumption of anxiolytic, especially among the female elders (Table 7). 
Citation: Soares E, de Souza Rossignoli P (2014) Depression and Cognitive Decline: Factors Related to Demographics and Psycho Pharmacotherapy on Elderly in Nursing Homes. J Psychiatry 17: 1000160. doi:10.4172/1994-8220.1000160

Page 4 of 9

\begin{tabular}{|c|c|c|c|c|c|c|c|}
\hline \multirow[t]{2}{*}{ Main Therapeutic Group } & \multirow{2}{*}{$\begin{array}{l}\text { Therapeutic-Pharmacological } \\
\text { Subgroup }\end{array}$} & \multirow{2}{*}{$\begin{array}{l}\text { Therapeutic/pharmacological/ } \\
\text { chemical Subgroup }\end{array}$} & \multirow[t]{2}{*}{$\%$} & \multicolumn{2}{|c|}{ Medicine/day } & \multicolumn{2}{|c|}{ Elders users } \\
\hline & & & & Male & Female & $\%$ & $\mathrm{n}$ \\
\hline \multirow[t]{2}{*}{ Psycholeptics (N05) } & $\begin{array}{l}\text { Anxiolytic } \\
\text { (N05B) }\end{array}$ & $\begin{array}{l}\text { Benzodiazepines } \\
\text { (N05BA) }\end{array}$ & 4,4 & 0,3 & 0,6 & 36,4 & 16 \\
\hline & $\begin{array}{l}\text { Antipsychotics } \\
\text { (N05A) }\end{array}$ & & 2,2 & 0,2 & 0,2 & 18,2 & 8 \\
\hline \multirow[t]{3}{*}{ Psychoanaleptics (N06) } & \multirow[t]{3}{*}{$\begin{array}{l}\text { Antidepressant } \\
\text { (N06A) }\end{array}$} & $\begin{array}{l}\text { Tricyclic } \\
\text { (N06AA) }\end{array}$ & 2,2 & - & 0,4 & 18,2 & 8 \\
\hline & & $\begin{array}{l}\text { Selective serotonin reuptake inhibitors } \\
\text { (SSRI) } \\
\text { (N06AB) }\end{array}$ & 3,8 & 0,4 & 0.3 & 14 & \\
\hline & & Atypical Antidepressant (N06AX) & 1,1 & - & 1 & 2 & \\
\hline Antiparkinson (N04) & Dopaminergic Agents (N04B) & & 1,1 & - & 0,2 & 9,1 & 4 \\
\hline $\begin{array}{l}\text { Others } \\
\text { (N07) }\end{array}$ & $\begin{array}{l}\text { Nootropic } \\
\text { (N07X) }\end{array}$ & & 2,2 & 0,1 & 0,3 & 18,1 & 8 \\
\hline
\end{tabular}

Table 7: Classification of medicines related to anatomical group of nervous system $(\mathrm{N})$ according to the ATC criteria and their consumption by 42 elders admitted in nursing homes in the city of Marilia, São Paulo, Brazil, in the year of 2013.

The most part of the elders is submitted to psychopharmacotherapy (Table 8). Data indicate that, in general, the elders who were medicated with neuropsychiatric medicine present smaller DP and CD isolated incidence. However, there is an inverse effect about (+) DP (+) $\mathrm{CD}$ incidence; the elders who were medicated with neuropsychiatric medicine present higher (+) DP (+) CD incidence (Table 8).

Comparing the data of the two groups (medicated with neuropsychiatric medicine and non-medicated) with the results of the tests (GDS and MMSE), it was found that the medicated elders present, in average, a larger symptomatology for DP than the nonmedicated ones. The inverse occurs in relation to $\mathrm{CD}$ indicatives, once elders medicated with neuropsychiatric medicine obtained smaller CD indicatives compared with non-medicated subjects (Table 8).

\begin{tabular}{|c|c|c|c|c|c|c|c|c|c|c|}
\hline \multirow{2}{*}{$\begin{array}{l}\text { Utilization of neuropsychiatric } \\
\text { medicine }\end{array}$} & \multirow[t]{2}{*}{$\%$} & \multirow[t]{2}{*}{$\mathrm{n}$} & \multicolumn{2}{|c|}{ (+) DP (-) CD } & \multicolumn{2}{|c|}{ (-) DP (+) CD } & \multicolumn{2}{|c|}{ (+) $\mathrm{DP}(+) \mathrm{CD}$} & \multirow{2}{*}{$\begin{array}{l}\text { Average } \\
\text { GDS }\end{array}$} & \multirow{2}{*}{$\begin{array}{l}\text { Average } \\
\text { MMSE }\end{array}$} \\
\hline & & & $\%$ & $\mathrm{n}$ & $\%$ & $\mathrm{n}$ & $\%$ & $\mathrm{n}$ & & \\
\hline Non-medicated & 45,8 & 19 & 12,5 & 6 & 16,7 & 8 & 16,7 & 8 & 9,9 & 19,9 \\
\hline Male & 25 & 10 & 8,3 & 4 & 8,3 & 4 & 8,3 & 4 & 11 & 21,3 \\
\hline Female & 20,8 & 9 & 4,1 & 2 & 8,3 & 4 & 8,3 & 4 & 8,8 & 18,6 \\
\hline Medicated & 54,2 & 23 & 4,1 & 2 & 4,1 & 2 & 33,3 & 16 & 12 & 21,7 \\
\hline Male & 25 & 11 & 4,1 & 2 & - & - & 12,5 & 6 & 9,5 & 23,1 \\
\hline Female & 29,2 & 12 & - & - & 4,1 & 2 & 20,8 & 10 & 14 & 20,6 \\
\hline
\end{tabular}

Table 8: DP and/or CD incidence on users and non-users of neuropsychiatric medicine on a sample of 42 elders admitted in nursing homes in the city of Marilia, São Paulo, Brazil, in the year of 2013.

The elders medicated only with psycholeptics (anxiolytic [ANX]; antipsychotics [ANP]) and psychoanaleptics (antidepressant [ADP]), isolated or in association, were distributed as presented in Table 9. Isolated incidence of DP occurred only on the elders who consumed $\mathrm{ADP}+\mathrm{ANX}$, while isolated CD occurred on the elders medicated with
$\mathrm{ADP}$ and ADP+ANP. (+) DP (+) CD occurred on the elders medicated with ADP or ANX and on the elders medicated with ADP + ANX and ADP+ANX+ANP (Table 9).

The average results of GDS and MMSE suggests that the indicatives of DP and CD among the elderly medicated with ADP and ANP are 
Page 5 of 9

low. Nevertheless, the indicators of DP and CD among elders medicated with ANX and all the associations between psycholeptics and psychoanaleptics medicines are high (Table 6).

Regarding the distribution by gender, it is important to observe that among the elderly that use only ADPs, the male present a smaller DP and $\mathrm{CD}$ indicative if compared to female. In relation to the DP indicatives among the female and male elders to whom ANX are administrated, there were no differences, and both genders obtained a high DP indicative. However, in relation to $\mathrm{CD}$, the male who consume only ANX presented a worst performance on MMSE than female. Among the male elders to whom is administrated ADP+ANX association, it was observed a higher DP and $\mathrm{CD}$ indicatives than in female. The use of ADP+ANP and ADP+ANX+ANP was only observed among the female elders, who presented DP and CD indicatives. In addition, the use of ANP was only observed among the male elders that presented strong DP indicative (Table 9).

\begin{tabular}{|c|c|c|c|c|c|c|c|c|c|c|}
\hline \multirow[t]{2}{*}{ Class/Association } & \multirow[t]{2}{*}{$\%$} & \multirow[t]{2}{*}{$\mathrm{n}$} & \multicolumn{2}{|c|}{ (+) DP (-) CD } & \multicolumn{2}{|c|}{ (-) DP (+) CD } & \multicolumn{2}{|c|}{$(+) \mathrm{DP}(+) \mathrm{CD}$} & \multirow{2}{*}{$\begin{array}{l}\text { Average } \\
\text { GDS }\end{array}$} & \multirow{2}{*}{$\begin{array}{l}\text { Average } \\
\text { MMSE }\end{array}$} \\
\hline & & & $\%$ & $\mathrm{n}$ & $\%$ & $\mathrm{n}$ & $\%$ & $\mathrm{n}$ & & \\
\hline ADP & 32 & 8 & - & - & 8 & 2 & 8 & 2 & 6,7 & 26,2 \\
\hline Male & 16 & 4 & - & - & - & - & - & - & 4 & 28,5 \\
\hline Female & 16 & 4 & - & - & 8 & 2 & 8 & 2 & 9,5 & 24 \\
\hline ANX & 16 & 4 & - & - & - & - & 16 & 4 & 18 & 22,5 \\
\hline Male & 8 & 2 & - & - & - & - & 8 & 2 & 18 & 21 \\
\hline Female & 8 & 2 & - & - & - & - & 8 & 2 & 18 & 24 \\
\hline ANP & 8 & 2 & - & - & - & - & - & - & 2 & 25 \\
\hline Male & 8 & 2 & - & - & - & - & - & - & 3 & 25 \\
\hline Female & - & - & - & - & - & - & - & - & - & - \\
\hline$A D P+A N X$ & 32 & 8 & 8 & 2 & - & - & 16 & 4 & 12,5 & 20 \\
\hline Male & 16 & 4 & - & - & - & - & 8 & 2 & 13 & 18 \\
\hline Female & 16 & 4 & 8 & 2 & - & - & 8 & 2 & 11,5 & 22 \\
\hline$A D P+A N P$ & 8 & 2 & - & - & 8 & 2 & - & - & 11,5 & 18,5 \\
\hline Male & - & - & - & - & - & - & - & - & - & - \\
\hline Female & 8 & 2 & - & - & 8 & 2 & - & - & 11,5 & 18,5 \\
\hline$A D P+A N X+A N P$ & 8 & 2 & - & - & - & - & 8 & 2 & 19,5 & 14,5 \\
\hline Male & - & - & - & - & - & - & - & - & - & - \\
\hline Female & 8 & 2 & - & - & - & - & 8 & 2 & 19,5 & 14,5 \\
\hline
\end{tabular}

Table 9: DP and/or CD incidence on users of psycholeptic and psychoanaleptic medicine and associations on a sample of 26 elders admitted in nursing homes in the city of Marilia, São Paulo, Brazil, in the year of 2013.

\section{Discussion}

The aim of the present study was to identify the prevalence of neuropsychiatric disorders, especially DP and CD, on a sample of nursing home residents, relating this prevalence with some aspects of the demographics and psycho pharmacotherapy.

Regarding to social demographic data was observed that the age average of the researched elders was 74,5 years old, which is coherent to the data of IBGE which indicate that the populations' average life expectancy is 74,8 years old in 2013 and 75,1 in 2014 [1]. In schooling terms, it was verified that $41,7 \%$ of the researched elders are nonliterate, surpassing the estimates achieved in 2003 by the Education Ministry, which defined that $30 \%$ of the elders in Brazil were nonliterate [35].
In relation to the prevalence of neuropsychiatric disorders, DP and $\mathrm{CD}$ indicatives were verified by the application of the GDS and MMSE, respectively. In relation to the prevalence of DP, GDS pointed out that $50 \%$ of the researched elders presented a light DP indicative, which is in agreement with researches that indicate a high prevalence of DP on geriatric populations [4,5]. The prevalence rate of symptomatology for DP found on this sample are consistent with the findings of Reynolds and Kupfer which estimate that the prevalence of geriatric DP on elders admitted in nursing homes is $60 \% 6$. It was observed a higher DP prevalence on male subjects [58,3\%]; however, it was not observed a significant difference between the average score obtained on male and female GDS, indicating that, in principle, the 'gender' variable would not be directly related to the DP prevalence on the elderly in nursing homes. The results of present study are in 
agreement to other studies in which the 'gender' variable was not proven to be significant [36-38], although in some studies it was observed a higher prevalence of DP in female elders [39,40]. It was observed a higher DP prevalence among the elders belonging to the $71-76[50 \%]$ and the 77-82 [37,5\%] age groups. From the analysis of the results, the 'age' variable shown to be significant, with the results pointing out to a positive regular correlation between age and DP, which reinforces, although some studies show the opposite $[37,38]$ the hypothesis that the increase of DP prevalence accompanies the age increase $[36,39,41,42]$.

In relation to the prevalence of $\mathrm{CD}$, the results of this study indicated that, from the application of MMSE, $54,2 \%$ of the elderly presented $\mathrm{CD}$. Although the results indicate a higher CD prevalence among female elders $[61,6 \%]$, it was not identified a relation between gender and $\mathrm{CD}(\mathrm{p}=0,565)$ and schooling and $\mathrm{CD}$, even though the absolute numbers have indicated a higher prevalence of elders with $\mathrm{CD}$ among the non-literate ones $[61,5 \%]$. It is important to consider that the female represented $60 \%$ of the non-literate elders.

The literature about the utilization of MMSE for the detection of CD have indicated the sensibility and trust of this instrument to detect DM on subjects with good schooling [43-45]. Furthermore, Srinivasan points out that the instrument presents little sensibility to detect light CD [46]. Other researches with larger samples indicated that male elders have a higher average score on MMES $(25,28)$ than the female $(24,51)[47,48]$. Therefore, the results of this study show to be coherent with the limitations pointed out in relation to MMSE. Related to the age, although the results point out to a negative, but not significant, correlation $(\mathrm{r}=-0,228 ; \mathrm{p}=0,284)$ between $\mathrm{CD}$ and age, it cannot be discarded, according to the appointments in the literature, the impact of age on the results obtained on MMSE is an important factor for CD prevalence $[28,49]$.

It was not surprising the fact that $33,3 \%$ of the researched elders presented (+) DP (+) CD. The results indicate also that elders with smaller CD indicative present less symptomatology for DP. These results are coherent with researches that have estimated between $25-50 \%$ of the CD prevalence among the elders with DP [50]. However, to the establishment of a cause-effect relation, there is no consensus in literature. While Jorm [51,52] considers that there are not enough evidences to affirm that DP is a risk factor for DM or CD, others researchers point $\mathrm{CD}$ as a secondary alteration to DP [53]. Due to the characteristics of the researched elders and the MMSE limitations already pointed, we believe that DP, on this sample, is shown to be precedent to $\mathrm{CD}$, which initially agrees with a tendency on the specialized literature that indicates DP as a risk factor for CD and DM [8,9,54-56].

Due to the high incidence of chronic diseases, $87,5 \%$ of the research subjects consumed some type of medicine. It was found an average of 8,6 continuous use medicine/elder/day from the medicated group, 9,7 medicine/female/day and 8,4 medicine/male/day, which corroborates others studies which reveal that the number of medicine utilized by elders admitted in nursing homes can be higher than seven by elder [57]. In addition, all the researched elders fit in polymedication [24,58-61] and chronicity [58,62]criteria of a larger.

The results show that $54,2 \%$ of the elders are submitted to psychopharmacotherapy and among all the medicine consumed, $17 \%$ was neuropsychiatric medicines [17\%] and was constituted basically by ANX [4,4\%], ANP [2,2\%] and ADP [7,1\%] and associations. Such results are alarming, considering that the consume of five or more medicine per day and the realization of pharmacological treatment for three or more different health problems are considered to be risk factors for the emergence of problems related to medicines (PRMs) [23]. Other researches also have observed an increase in consumption of neuropsychiatric medicines on the elderly, estimating that the prevalence of these medicines among elders admitted in nursing homes reaches up to $63,0 \%$ [63].

Female elders consumed almost double of neuropsychiatric medicine per day than the male (relation of 1,8 by one), and this data corroborate the appointment made by other studies which attribute the female gender as a factor positively related to a higher consumption of medicines [21,22,25,64]. Furthermore, the neuropsychiatric medicines adopted for this sample follow the tendency pointed in the literature for the treatment of mood disorders in the elderly [65-67].

It is interesting to observe that, among the female subjects, even though is not statistically significant, there was a higher $\mathrm{CD}$ prevalence [61,6\%] and lower DP prevalence [58,3\%] if compared to the male subjects. Such results suggest that, for this sample, the polymedication and chronicity can be considered PRMs and risk factors for CD. In fact, as previously suggested, the elderly women are more polymedicated than the elderly men, and the polymedication among the elderly women have been associated to a worsening of the functional capacity as a result of CD caused by the medicine [68].

Nevertheless, one fact would put, in principle, this hypothesis in suspension: the results of this study indicated that elders medicated with neuropsychiatric medicines presented less DP $(4,1 \%$ of the medicated against $12,5 \%$ of the non-medicated) and CD $(4,1 \%$ of the medicated against $16,7 \%$ of the non-medicated) incidences in comparison with elders who were non-medicated. Meanwhile, an inverse effect occurs when the incidence of $(+)$ DP (+) CD is evaluated; among the elders who were medicated with neuropsychiatric medicines, 33,3\% presented (+) DP (+) CD, while that from the nonmedicated only $16,7 \%$ presented $(+) \mathrm{DP}(+) \mathrm{CD}$. Thus, taken together, these results strongly suggest that the polymedication and chronicity can be considered PRMs and risk factors for neuropsychiatric disorders. In this sense, although some studies do not point out the association between the use of neuropsychiatric medicines and the prevalence of CD [69], other studies demonstrate this association [68]. Mental confusion and impairment in memory caused by attention deficit have been described as clinical consequences of the utilization of not only neuropsychiatric medicines, such as ADP, ANX and ANP, but also of other medicine classes, such as beta blockers [70] and antiulcers [71].

However, these findings are weakened again when we compare the general data of both groups (medicated and non-medicated with neuropsychiatric medicines) with the results of MMSE, because the results indicate that medicated elders present, in average, smaller CD prevalence (21,7 average/points/medicated against 19,9 average/ points/non-medicated). Due to these results, should the correlation between psychopharmacotherapy and neuropsychiatric disorders be discarded? We believe that no if other factors are considered: the use of ANX isolated and the association between neuropsychiatric medicines.

In fact, individuals medicated only with ANX (benzodiazepines) presented, from the MMSE and GDS averages, CD and DP indicatives, which suggests that this type of medicine can be associated to the prevalence of such disorders. The ANX are Central Nervous System 
depressor medicines and, due to this characteristic, it becomes a fundamental medication for anxiety treatment. However, it is exactly this Central Nervous System depression that negatively affect DP symptomatology among elders [72]. The chronic use of diazepam, a ANX, is directly related with the increase of symptoms of anguish, articular pains, depression and dizziness [71,73]. However, the utilization of other medicines, such as anti-hypertensives, is also related to the worsening of depressive symptoms among elders [71].

Furthermore, the CD and DP indicatives are elevated in elders using neuropsychiatric medicines associations. The association between antidepressants and antipsychotics increases the incidence of mental confusion among elders [71], what could be related to the increase of $\mathrm{CD}$. Others associations that do not evolve neuropsychiatric medicine, such as cimetidine and captopril, also lead to mental confusion [71]. In addition, it have been also demonstrated that the depressive symptoms are significantly related with medicine associations [74]. It is clearly descripted in the literature that ANX, especially benzodiazepine, can have its depressor effect intensified by the concomitant use of ANP and ADP75. In this manner, taking also under consideration the neuropsychiatric medicines associations, the polymedication and chronicity as risk factors for CD and DP must be considered. Our results show that the higher the neuropsychiatric medicines associations, the higher are the prevalence for DP and CD symptomatology.

It is important to highlight as an aggravating factor for the exposed scenery, the fact that the elders to whom those associations are administrated already are highly emotional and/or physical and/or cognitive debilitated. Furthermore, it is important to point out that the elderly population presents physiological particularities that influence directly on the medicines' pharmacokinetics and pharmacodynamics $[70,76]$. These alterations, summed to polymedication (with the massive use of neuropsychiatric medicines) and chronicity, as previously presented, render the elders to be more vulnerable to PRMs occurrences, which elevates the mortality $[25,64,70,77-80]$.

In this manner, the increase of CD and DP incidence among the studied elders can be considered, at least partially, as a consequence of the utilization of medicines. Furthermore, the MMSE and GDS tests applied to the elders medicated with neuropsychiatric medicine indicate that, the higher the symptomatology for DP, the higher the CD indicatives, which reinforces the DP as a risk factor for CD and DM $[9,54-56,68]$.

\section{Final Considerations}

Other deeper investigations with larger samples and composed by elders resident in community and nursing homes with varied demographic characteristics are necessary to verify the coherence of these findings, and also to comprehend the nature of neuropsychiatric disorders on geriatric populations. Precise definitions and proper, sensitive and specific measurements are equally necessary for the comprehension of the nature of neuropsychiatric disorders in geriatric populations. The study of the relation between neuropsychiatric medicines associations and CD and/or DP must be deepened considering the pharmacological properties of the medicines and the context in which they are administrated. It is a fact that the medicines play a central role in the search for recovery of health and life quality, being an essential element of professional practices. However, the utilization of medicines must be considered by the health professionals as an additional tool, accessory to the steps of preventive feature and health promotion for the population, mainly in the elderly. On the other hand, there is no necessity for more studies to determine that elders admitted in nursing homes became weaker and, consequently, more susceptible to neuropsychiatric disorders. The solution is simple: a change of conjuncture (social, educational, political, and economical, etc.). The difficulty: implement them.

\section{References}

1. IBGE - Instituto Brasileiro de Geografia e Estatística. Projeção da população do Brasil por sexo e idade para o período 2000/2060. 2013. Brasília: Ministério do Planejamento, Orçamento e Gestão - IBGE.

2. Stroud JM, Steiner V, Iwagwu C (2008) Predictors of depression among older adults with dementia. Dementia 7: 1127-138.

3. Corrêa, ACO (1997) Depressão e poliqueixas no idoso. J Bras Psiquitr 46: 13-6.

4. Soares E, Demartini SM, Suzuki MM (2012) Estudo epidemiológico do perfil do idoso institucionalizado em instituições do interior paulista. Rev Ciência em Extensão 8: 35-59.

5. Blay SL, Bickel H, Cooper B (1999) Mental illness in cross- national perspective. Results from a Brazilian and German community survey among the elderly. Soc Psychiatr Epidemiol 26: 245-51.

6. Reynolds CF, Kupfer DJ (1999) Depression and aging: a look to the future. Psychiatr Serv 50: 1167-72.

7. Lebowitz, BD, Pearson JL, Schneider, LS (1997) Diagnosis and treatment of depression in late life consensus statement update. JAMA 278: 1186-119.

8. Alexopoulos GS, Borson S, Cuthbert BN (2002) Assessment of late life depression. Biol Psychiatry 52: 164-74.

9. Alexopoulos GS, Buckwalter K, Olin J (2002) Comorbidity of late life depression: an opportunity for research on mechanisms and treatment. Biological Psychiatry 52: 543-58.

10. Gallo JJ, Rabins PV (1999) Depression without sadness: alternative presentations of depression in late life. Am Fam Physician 60: 820-6.

11. Baer LH, Tabri N, Blair M (2013) Longitudinal Associations of Need for Cognition, Cognitive Activity, and Depressive Symptomatology With Cognitive Function in Recent Retirees. J Gerontol B Psychol Sci Soc Sci 68: 655-664.

12. Gatz JL, Tyas SL, St. John, PS (2005) Do Depressive Symptoms Predict Alzheimer's Disease and Dementia? J Gerontol A Biol Sci Med Sci. 60: 744-747.

13. Murray CJ, Lopez AD (1997) Global mortality, desability, and the contribution of risk factors: Global Burden of Disease Study. The Lancet 349: 1436-42.

14. APA - American PsychiatricAssociation. (2008) Manual diagnóstico e estatístico de transtornos mentais - DSM-IV-TRTM.Porto Alegre: Artmed.

15. Charchat-Fichman H, Caramelli P, Samesshima K et al. (2005) Declínio da capacidade cognitiva durante o envelhecimento. Rev Bras Psiq 27: 79-82.

16. Katzman R. (1993) Education and the prevalence of dementia and Alzheimer's disease. Neurology 43: 13-20.

17. Roe CM, Xiong C, Miller JP (2007) Education and Alzheimer disease without dementia: support for the cognitive reserve hypothesis. Neurology 68: 223-8.

18. Veras R (2003) Em busca de uma assistência adequada à saúde do idoso: revisão da literatura e aplicação de um instrumento de deteç̧ão precoce $\mathrm{e}$ de previsibilidade de agravos. Cad Sau Publ 19:705-15.

19. Cedeño AMR, Vazquez PMM, Leon JLF (2000) Determinación de poli farmacoterapia en pacientes geriátricos de un consultorio del médico de la familia en Cienfuegos. Rev Cubana Farm 34: 170-174.

20. Patel RB (2003) Polypharmacy and the elderly. J Infus Nurs 26: 166-9.

21. Filho AIL, Uchoa E, Lima-Costa MF (2006) Estudo epidemiológico de base populacional sobre uso de medicamentos entre idosos na Região 
Metropolitana de Belo Horizonte, Minas Gerais, Brasil. Cad. Saúde Pública 22: 2657-2667.

22. Silva AL, Ribeiro AQ, Klein CH et al. ( 2012) Utilização de medicamentos por idosos brasileiros, de acordo com a faixa etária: um inquérito postal. Cad. Saúde Pública 28: 1033-1045.

23. Langford BJ, Jorgenson D, Kwan D (2006) Implementation of a selfadministered questionnaire to identify patients at risk for medication related problems in a family health center. Pharmacotherapy 26: 260-268.

24. Flores LM, Mengue SS (2005) Uso de medicamentos por idosos em região do sul do Brasil. Rev Saúde Pública 39: 924-9.

25. Lima-Costa MF, Barreto SM, Giatti, L (2003) Condições de saúde, capacidade funcional, uso de serviços de saúde e gastos com medicamentos da população idosa brasileira: um estudo descritivo baseado na Pesquisa Nacional por Amostra de Domicílios. Cad. Saúde Pública 19: 735-743.

26. Veras R (2009) Envelhecimento populacional contemporâneo: demandas, desafios e inovações. Rev. Saúde Pública 43: 548-554.

27. . Perlini NMOG, Leite MT, Furini AC (2007) Em busca de uma instituição para a pessoa idosa morar: motivos apontados por familiares. Rev Escola de Enfermagem da USP 41: 229-36.

28. Soares E, Coelho MO, Carvalho SMR (2012) Capacidade funcional, declínio cognitivo e depressão em idosos institucionalizados: possibilidade de relações e correlações. Kairós Gerontol 15: 117-39.

29. Yesavage JA, Brink TL, Rose TL (1983) Development and validation of a geriatric depression screening scale: a preliminary report. J Psychiat Res17: 37-49.

30. Folstein MF, Folstein SE, Mchugh, PR (1975) Mini-mental state: a practical method for grading the cognitive state of patients for the clinician. J Psychiatric Res 12:189-198.

31. Hernandéz SPS, Mocetzuma L (1999) Depresión en población adulta mayor: tamizage en unidade de primer nivel de atención médica. Rev Med IMSS 37: 111-5.

32. Tombaugh TN, Mcintyre NJ (1992) The mini-mental state examination: a comprehensive review. Jounal of the American Geriatrics Society 40: 922-35.

33. Anthony JC, Leresche L, Niaz U (1982) Limits of the mini-mental state as a screening test for dementia and delirium among hospital patients. Psychological Medicine 12: 397-408.

34. WHO collaborating Centre for Drug Statistics Metholology (2014) Guidelines for ATC classification and DDD assignment 201317 ed. Olso: WHO.

35. MEC - Ministério da Educação (2003) Mapa do analfabetismo no Brasil Brasília: Ministério da Educação e Cultura - INEP.

36. Schoevers RA, Beekman AT, Deeg DJ (2000) Risk factors for depression in later life: results of a prospective community based study (AMSTEL). J Affect Disord 59: 127-37.

37. Prince MJ, Harwood RH, Thomas A (1998) A prospective populationbased cohort study of the effects of disablement and social milieu on the onset and maintenance of late-life depression. The Gospel Oak Project VII. Psychol Med 28: 337-50.

38. Turvey CL, Carney C, Arndt S (1999) Conjugal loss and syndromal depression in a sample of elders aged 70 years or older. Am J Psychiatry 156: 1596-601.

39. Roberts RE, Kaplan GA, Shema SJ (1997) Does growing old increase the risk for depression? Am J Psychiatry 154: 1384-90.

40. Geerlings SW, Beekman AT, Deeg DJ (2000) Physical health and the onset and persistence of depression in older adults: an eight-wave prospective community-based study. Psychol Med 30: 369-80.

41. Heun R, Hein S (2005) Risk factors of major depression in the elderly. Eur Psychiatry 20: 199204.

42. Harris T, Cook DG, Victor C, DeWilde S (2006) Onset and persistence of depression in older people--results from a 2-year community follow-up study. Age Ageing 35: 25-32.
43. Rosselli D, Ardila A, Pradilla G (2000) The Mini-Mental State Examination as a selected diagnostic test for dementia: a Colombian population study. Rev de Neurologia 30: 428-32.

44. Gurian MF, Oliveira RC, Laprega MR (2012) Rastreamento da função cognitiva de idosos não institucionalizados. Revista Brasileira de Geriatria e Gerontologia15: 275-284.

45. Valle EA, Costa EC, Firmo JO (2009) Estudo de base populacional dos fatores associados ao desempenho no Miniexame do Estado Mental entre idosos: projeto Bambuí. Cad Sau Publ 25: 918-926.

46. Srinivasan $S$ (2010)The concise cognitive test for dementia screening: Reliability and effects of demographic variables as compared to the mini mental state examination. Neurology India 58: 702-7.

47. Pinzan-Faria VM, Iório MCM (2010) Sensibilidade auditiva e autopercepção do handicap: um estudo em idoso. Distúrbios da Comunicação 16: 289-99.

48. Argimon IIL, Lopes, RMF, Terroso, LB (2012) Gênero e escolaridade: estudo através do miniexame do estado mental (MEEM) em idosos. Aletheia 39: 153-161.

49. Almeida OP (1998) Mini-exame do estado mental e o diagnóstico de demência no Brasil. Arquivos de Neuropsiquiatria 56: 605-12.

50. Ganguli M, Du Y, Dodge HH (2006) Depressive symtoms and cognitive decline in late life: A Prospective Epidemiological Study. Archives of General Psychiatry 63: 153-160.

51. Jorm AF (2000) Is depression a risk factor for dementia or cognitive decline?Gerontology 46: 219-27.

52. Jorm AF, Christensen H, Korten AE (2001) Memory complaints as a precursor of memory impairment in older people: a longitudinal analysis over 7-8 years. Psychological Medicine 31: 441-9.

53. Rapp MA, Dahlman K, Sano M (2005) Neuropsychological differences between late-onset and recurrent geriatric major depression. Am J Psych 162: 691-8.

54. Yochim BP, MacNeill SE, Lichtenberg PA (2006) Vascular depression" predicts verbal fluency in older adults. J Clinl and Exp Neuropsych 28: 495-508.

55. Ownby RL, Crocco E, Acevedo A (2006) Depression and risk for Alzheimer disease: systematic review, meta-analysis, and metaregression analysis. Arch General Psychiatry 63: 530-38.

56. Edwards, ER, Lindquist K, Yaffe K (2004) Clinical profile and course of cognitively normal patients evaluated in memory disorders clinics. Neurology 62: 1639-42.

57. Castellar J, Karnikowski MGO, Vianna LG (2007) Estudo da farmacoterapia prescrita a idosos em Instituição Brasileira de Longa Permanência. Acta Med. Port 20: 97-105.

58. Bjerrum L, Sogaard J, Hallas J (1999) Polypharmacy in general practice: differences between practitioners. Br J Gen Pract 49:195-98.

59. Mamum K, Lien CT, Goh-Tan CY (2004) Polypharmacy and inappropriate medication use in Singapore nursing homes. Ann. Acad. Med. Singapore 33: 49-52.

60. Lucchetti G, Granero AL, Pires SL (2010) Fatores associados à polifarmácia em idosos institucionalizados. Rev. Bras. Geriatr. Gerontol 13: $51-58$.

61. Fochat RC, Horsth RBO, Sette MS (2012) Perfil de utilização de medicamentos por idosos frágeis institucionalizados na Zona da Mata Mineira, Brasil. Rev. Ciênc. Farm. Básica Apl 33: 447-454.

62. Veehof LJG, Stewart RE, Haaijer-Ruskamp B (2000) The development of polypharmacy: a longitudinal study. Fam Pract 17: 261-67.

63. Stella F, Caetano D, Pacheco JL (2006) Factors influencing psychotropic prescription by non-psychiatrist physicians in a nursing home for the elderly in Brazil. Sao Paulo Med J 124: 253-256.

64. Rozenfeld S (2003) Prevalência, fatores associados e mau uso de medicamentos entre os idosos: uma revisão. Cad. Saúde Pública 19: 717-724.

65. Mulrow CD, Williams JW, Chiquette E (2000) Efficacy of newer medications for treating depression in primary care patients. The American Journal of Medicine 108: 54. 
Citation: Soares E, de Souza Rossignoli P (2014) Depression and Cognitive Decline: Factors Related to Demographics and Psycho Pharmacotherapy on Elderly in Nursing Homes. J Psychiatry 17: 1000160. doi:10.4172/1994-8220.1000160

Page 9 of 9

66. Roose SP, Schatzberg AF (2005) the efficacy of antidepressants in the treatment of late-life depression. J Clin Psychopharmacol 25: S1-7.

67. Trivedi MH, Fava M, Wisniewski SR (2006) Medication Augmentation after the Failure of SSRIs for Depression. N Engl J Med 354: 1243-52.

68. Nogueira SL, Ribeiro RCL, Rosado LLEFPL (2010) Fatores determinantes da capacidade funcional em idosos longevos. Ver Bras Fisioter 14: 322-329.

69. Bicca MG, Rusch SGS, Argimon IIL (2008) Habilidades cognitivas em idosas institucionalizadas: estudo comparativo do desempenho de usuárias e não usuárias de benzodiazepínicos. Kairós 11:203-216.

70. Secoli SR (2010) Polifarmácia: interações e reações adversas no uso de medicamentos por idosos. Rev. Bras. Enf 63:136-140.

71. Botosso RM, Miranda EF, Fonseca MAS (2011) Reação adversa medicamentosa em idosos. RBCEH 8:285-297.

72. Brunton L, Chabner B, Knollman B (2010) Goodman and Gilman's The Pharmacological Basis of Therapeutics McGraw-Hill Professional.

73. Cruz AV, Fulone I, Alcalá M (2006) Uso crônico de diazepam em idosos atendidos na rede pública em Tatuí-SP. Ver Ciênc Farm Básica Apl 27: 259-267.
74. Hoffman EJ, Ribeiro F, Farneze JM (2010) Sintomas depressivos e fatores associados entre idosos residentes em uma comunidade no norte de Minas Gerais, Brasil. J Bras Psiquiatr 59:190-197.

75. Baxter K, Preston C (2013) Stockley's Drug Interactions. Pharmaceutical Press.

76. Faria MQ, Franceschini SCC, Ribeiro AQ (2010) Estado nutricional e uso de medicamentos por idosos. Lat. Am. J. Pharm 29:127-131.

77. Gorzoni ML, Fabbri RMA, Pires SL (2008) Critérios de Beers-Fick e medicamentos genéricos no Brasil. Rev. Assoc. Med. Bras 54: 535-6.

78. Bueno CS, Oliveira KR, Berlezi EM (2009) Utilização de medicamentos e risco de interações medicamentosas em idosos atendidos pelo Programa de Atenção ao Idoso da Unijuí. Rev Ciênc Farm Básica Apl 30: 331-338.

79. Camarano AA, Kanso S, Pasinato MT (2005) Idosos brasileiros indicadores de condições de vida e de acompanhamento de políticas. Brasília: Presidência da República/Subsecretária de Recursos Humanos.

80. Galato D, Silva ES, Tibúrcio LS (2010) Estudo de utilização de medicamentos em idosos residentes em uma cidade do sul de Santa Catarina (Brasil): um olhar sobre a polimedicação. Ciênc. Saúde Coletiva 15: $2899-2905$ 